\title{
Os projetos de abolição de Joaquim Nabuco e Luís Gama
}

\author{
Sales Augusto dos Santos ${ }^{1}$ \\ Luis Gustavo de Paiva Faria²
}

\begin{abstract}
RESUMO
Objetivando contribuir com o estudo da história e cultura afro-brasileiras e, consequentemente, apondo-se à colonialidade do poder e do saber, neste artigo visamos comparar os projetos de abolição de Joaquim Nabuco e de Luís Gama, realizando um levantamento parcial de suas respectivas características e pressupostos. Assim, verificamos diferenças e semelhanças entre as suas propostas e seus posicionamentos políticos e ideológicos para concretizá-las. Sustenta-se o argumento de que o projeto de abolição assumido por Nabuco, entendido aqui como um representante das elites dirigentes daquele contexto histórico, é diametralmente oposto ao projeto de Luís Gama, ex-escravizado que logrou ser poeta e advogado antiescravista. Ambos agem como intelectuais orgânicos de suas classes de origem. O primeiro defendia que a abolição fosse conduzida pelos homens livres, mas deliberada no Parlamento; portanto, sem a participação dos/as escravizados/as e com o objetivo último de embranquecer o Brasil. O segundo defendia que a conquista da liberdade tivesse participação efetiva dos/as escravizados/as, incluindo a possibilidade de uso da violência, como, por exemplo, o assassinato dos senhores pelos/as escravizados/as.
\end{abstract}

Palavras-chave: Luís Gama; Joaquim Nabuco; projeto de abolição.

\section{Joaquim Nabuco's and Luís Gama's projects of abolition}

\begin{abstract}
Aiming to contribute to the study of Afro-Brazilian history and culture and, consequently, to stand against the coloniality of power and knowledge, this article aims to compare Joaquim Nabuco's and Luís Gama' abolition projects, carrying out a partial survey of their respective characteristics and assumptions. Thus, we verify differences and similarities between their proposals and their political and ideological positions to achieve them. It is argued that the abolition project assumed by Nabuco, understood here as a representative of the ruling elites of that historical context, is diametrically opposed to Luis Gama's project, a formerly enslaved man who succeeded to be an anti-slavery poet and advocate. Both act as organic intellectuals of their classes of origin. The first argued that abolition should be conducted by free men, but deliberate in Parliament; therefore, without the participation of the enslaved ones and with the ultimate objective of whitening

\footnotetext{
1 Doutor em Sociologia pela Universidade de Brasília (UnB). Instituto Nacional de Ciência e Tecnologia de Inclusão no Ensino e na Pesquisa (INCTI) da Universidade de Brasília (UnB), Brasília, DF, Brasil. Orcid iD: http://orcid.org/0000-0002-0856-6653. E-mail: salesaugustodossantos@gmail.com

2 Mestrando em Estudos Literários pela Universidade Federal de Viçosa (PPGLET/UFV). Viçosa, Minas Gerais, Brasil. Orcid iD: http://orcid.org/0000-0003-0603-4642. E-mail: Igpaivafaria@gmail.com
} 
Brazil. The second argued that the conquest of freedom should have effective participation of the enslaved, including the use of violence, such as the murder of the lords by the enslaved.

Keywords: Luís Gama; Joaquim Nabuco; abolition project.

\section{Los proyectos de abolición de Joaquim Nabuco y Luís Gama}

\section{RESUMEN}

Con el objetivo de contribuir al estudio de la historia y la cultura afrobrasileña y, en consecuencia, de oponerse a la colonialidad del poder y del conocimiento, este artículo tiene como objetivo comparar los proyectos de abolición de Joaquim Nabuco y de Luís Gama, realizando un levantamiento parcial de sus respectivas características y presupuestos. Así, constatamos diferencias y similitudes entre las dos propuestas y sus posicionamientos políticos e ideológicos para concretizarlas. Se sostiene que el proyecto de abolición asumido por Nabuco, comprendido como un representante de las élites dirigentes de aquel contexto histórico, es diametralmente opuesto al proyecto de Luís Gama, ex esclavo que logró ser poeta y abogado antiesclavista. Ambos actúan como intelectuales orgánicos de sus clases de origen. El primero, defendía que la abolición se llevara a cabo por hombres libres, pero decidida en el Parlamento; por tanto, sin la participación de los/las esclavizados/as y con el objetivo final de blanquear el país. El segundo, por su parte, defendía que la conquista de la libertad tuviera la participación efectiva de los/las esclavizados/as, incluso haciendo uso de la violencia, como, por ejemplo, a través del asesinato de los hacendados por los/as esclavos/as.

Palabras clave: Luís Gama; Joaquim Nabuco; proyecto de abolición.

\section{Introdução}

Filho de uma negra livre, mas escravizado após ser vendido aos dez anos de idade pelo próprio pai, Luís Gonzaga Pinto da Gama foi uma personagem peculiar nas vidas política e cultural brasileira do século XIX (FERREIRA, 2007). Residente à época na província de São Paulo, foi um autodidata em diversas áreas do conhecimento, tendo atuado profissionalmente como advogado, jornalista e poeta. Após aprender a ler e escrever, descobriu documentos que confirmavam aquilo de que ele tinha convicção - a ilegalidade e a injustiça de sua escravização - isso depois de anos exercendo ofícios de um escravizado urbano. Fugiu dessa condição para tornar-se um homem livre. Mas, mais do que isso, foi um sujeito 
engajado na política de seu tempo, visto que era assumidamente um republicano radical. Assim, foi opositor sem tréguas da escravidão, tendo atuado como abolicionista, libertando pessoalmente mais de quinhentos escravizados (GAMA, 2005, p. 170), bem como foi crítico de instituições conservadoras como a Igreja Católica e o Império (FERREIRA, 2007; MOURA, 2005).

É notável, contudo, a pequena atenção com que é tratada a trajetória de Luís Gama nos currículos escolares e universitários quando comparada a de outros intelectuais que trataram de temas idênticos ou semelhantes aos que esse autor enfrentou, como, por exemplo, o também abolicionista Joaquim Nabuco, contemporâneo de Gama, assim como Castro Alves, poeta cuja temática de apelo ao abolicionismo e ao antiescravismo estava também presente na obra poética de Gama, ainda que sob uma perspectiva social distinta. Enquanto Castro Alves assumia-se como um interlocutor dos negros escravizados, Gama enunciava e encarnava a própria voz dos/as escravizados/as, até porque fora escravizado, questionando as instituições e a posição subalternizada e desumana dos negros na estrutura social oitocentista (FERREIRA, 2017). Sobre isso, a escritora Zilá Bernd assim os distingue:

\footnotetext{
Para nós, Luís Gama representa uma poesia do negro, enquanto Castro Alves [está] ligado a uma vertente poética que elegeu o negro e sua desditosa condição na América como foco temático principal. Enquanto Castro Alves critica as regras do jogo que permitiam que houvesse escravos, Luís Gama vai além e critica o próprio jogo: o falso humanitarismo dos que defendiam a abolição (...). A poesia de Luís Gama corresponde a uma fala transgressora que atinge 0 branco com o próprio instrumento que este criou para marginalizá-lo. (BERND, 1988, p. 56-67)
}

Diferentemente do autor de ascendência africana, Joaquim Nabuco julgava ter um mandato dos/as escravizados/as ou, como ele mesmo afirmou, tinha a "procuração" dos oprimidos (NABUCO, 1938, p. 26), pensamento ratificado pelo sociólogo Fernando Henrique Cardoso durante o seu discurso de posse como presidente do Brasil, em 01 de janeiro de 1995, no Congresso Nacional: 
Joaquim Nabuco, o grande propagandista do abolicionismo, pensava em si mesmo e em seus companheiros como titulares de um "mandato da raça negra" - mandato que não era dado pelos escravos, pois eles não teriam meios de reclamar seus direitos, mas que os abolicionistas assumiam mesmo assim (...). (CARDOSO, 1995, p. 27)

Branco, de origem de família escravocrata, filho do Senador José Tomás Nabuco de Araújo Filho, que também foi ministro da Justiça, o abolicionista Joaquim Nabuco falava em nome dos/as escravizados/as, mas a partir de um ponto de vista dos senhores da casa grande, uma vez que seu objetivo último era embranquecer o Brasil (SANTOS, 1997). Como o pai, Joaquim Nabuco também exerceu cargos públicos e políticos, visto que foi deputado federal pela província de Pernambuco nos períodos de 1879 a 1880 e de 1885 a 1889, assim como embaixador do Brasil nos Estados Unidos da América (EUA), de 1905 a 1910. Além disso, foi um dos fundadores da Academia Brasileira de Letras (ABL). Mas o importante a destacar aqui é que Joaquim Nabuco não foi citado à toa por Cardoso (1995). Como esse último já afirmou, Nabuco o influenciou política e sociologicamente (CARDOSO, 2013). Ou seja, Nabuco era e ainda é um intelectual amplamente reconhecido no meio acadêmico brasileiro, ao contrário de Luís Gama. Ou seja, o primeiro, teve e tem visibilidade acadêmico-política, ao contrário do último, que é um exemplo de marginalização literária e histórica, mesmo após o advento das Leis 10.639/2003 e 11.645/2008. ${ }^{3}$

Portanto, o presente artigo objetiva comparar os projetos de abolição de Joaquim Nabuco e de Luís Gama, realizando um levantamento parcial de suas respectivas características e pressupostos.

\footnotetext{
${ }^{3}$ A Lei 10.639, de 09 de janeiro de 2003, tornou obrigatório o "estudo da História da África e dos Africanos, a luta dos negros no Brasil, a cultura negra brasileira e o negro na formação da sociedade nacional, resgatando a contribuição do povo negro nas áreas social, econômica e política pertinentes à História do Brasil". Disponível em: http://www.planalto.gov.br/ccivil_03/LEIS/2003/L10.639.htm. Acesso em: 17 dez. 2018. Essa lei foi alterada pela Lei 11.645, de 10 de março de 2008, que também inclui a história dos indígenas. Disponível em: http://www.planalto.gov.br/ccivil_03/_Ato20072010/2008/Lei/L11645.htm. Acesso em: 17 dez. 2018.
} 


\section{As elites dirigentes brasileiras e o processo de abolição}

Segundo Santos (1997, p. 11-12), o período de transição do trabalho cativo para o trabalho livre no Brasil, que tem início na segunda metade do século XIX, geralmente é interpretado através da noção de herança da escravidão, como em Fernandes e Bastide (1955), Fernandes (1978) e Cardoso (1960), segundo a qual os negros no período pós-abolição não compuseram o quadro de trabalhadores do emergente mercado de trabalho livre por conta dos caracteres culturais internalizados durante $\mathrm{O}$ período em que estiveram escravizados, motivo pelo qual os imigrantes europeus foram escolhidos em detrimento daqueles.

Em que pese a plausibilidade desse argumento, Santos (1997) interpreta e/ou compreende a formação desse mercado sob óptica distinta, isto é, não focada apenas na socialização dos/as negros/as no e para o trabalho escravizado (cf. FERNANDES e BASTIDE, 1955; FERNANDES, 1978), isto é, dos/as negros/as como portadores/as de "mentalidade e (...) hábitos de escravos, que eram incompatíveis com o trabalho assalariado livre nas indústrias" (CARDOSO, 1960, p. 43). Para Santos (1997) não se pode desconsiderar a perspectiva racista dos ex-fazendeiros e futuros capitães da indústria naquele momento de gênese do patronato industrial brasileiro. Perspectiva que é indicada por meio de um dos discípulos de Florestan Fernandes, Octávio lanni, quando esse afirma que "o dilema que cerca a existência do negro, depois de 1888, se resume nos seguintes termos: nem ele estava preparado para vender a sua força de trabalho nem o empresário estava preparado para comprá-la." (IANNI, 1972, p. 216).

Infelizmente lanni (1972) não explorou o fato de que o empresário não estava preparado para comprar a força de trabalho dos/as negros/as no início da formação do mercado de trabalho livre no Brasil. Caso tivesse seguido essa trilha, observaria que o racismo fazia parte das "condições culturais herdadas da escravatura" pelos empresários. Portanto, estas condições culturais não afetaram somente os/as ex-escravizados/as, como demonstrou Santos (1977), até porque, como afirmaram Fernandes (1972, p. 
71) e Bastide e Fernandes (1955, p. 74 e 80), o preconceito e a discriminação raciais eram inerentes ao escravismo brasileiro. Por conseguinte, impossível não pensar que razões fundadas em preconceito e discriminação raciais não tenham influenciado o patronato da época na escolha de seus trabalhadores para o mercado de trabalho livre emergente, fato que fica explícito durante a realização do Congresso Agrícola realizado em 1878, no Rio de Janeiro, onde o universo mental dos fazendeiros, especialmente os da região Sudeste, se manifesta extremamente preconceituoso e discriminador contra o trabalhador nacional, especialmente contra os/as negros/as, assim como contra os/as asiáticos/as (cf. EISENBERG, 1980).

A diversificação analítica assumida por Santos (1997), em que diversos atores sociais ${ }^{4}$ são considerados, aglutina alguns grupos sociais na categoria "elites dirigentes", um dos atores sociais fundamentais para a compreensão dos fenômenos políticos e econômicos envoltos ao tema da abolição ${ }^{5}$. $O$ que denominamos de elites dirigentes, corroborando a argumentação de Santos (1997), é a agregação das elites econômica, política e intelectual da época, formando um bloco coeso, especialmente no que diz respeito à escolha (racial) dos então futuros trabalhadores livres brasileiros.

Embora alguns membros dessas elites possam se enquadrar em todos os tipos de elites supracitados, como é o caso de Joaquim Nabuco, filho de latifundiário, político e intelectual (por isso a agregação acima), para fins didáticos também podemos dividir essas elites, ou seja, vê-las separadamente em face dos interesses conjunturais e/ou imediatos de cada uma delas. Porém, o importante aqui é perceber que a atuação dessas elites no processo de abolição deve ser pensada a partir das três modalidades mencionadas acima, já que mobilizava interesses econômicos, atuações políticas e justificativas intelectuais.

\footnotetext{
${ }^{4}$ Conforme o sociólogo Alain Touraine (1994, p. 220-221), "ator não é aquele que age em conformidade com o lugar que ocupa na organização social, mas aquele que modifica o meio ambiente material e sobretudo social no qual está colocado, modificando a divisão do trabalho, as formas de decisão, as relações de dominação ou as orientações culturais".

5 Santos $(1997,2014)$ também considera fundamental a ação dos/as escravizados/as negros/as na luta contra o sistema escravista brasileiro. Mas, ante a brevidade que o espaço exige para produção desse artigo, não analisaremos todas as reflexões de desse autor e focaremos nas elites dirigentes brasileiras da virada do século XIX para o XX.
}

Revista Exitus, Santarém/PA, Vol. 10, p. 01-31, e020078, 2020. 
O argumento que sustentamos, baseado em Santos (1997, p. 77-78), é de que as pressões externa e interna para o fim da escravidão foram conduzidas pelas elites dirigentes de modo a manter uma estabilidade política através de um processo lento, gradual e seguro (para essas elites), ancorado principalmente em três leis: a Lei do Ventre Livre, de 1871, a Lei do Sexagenário, de 1885, e a Lei Áurea, de 1888.

Essas leis embasaram um processo relativamente estável da abolição do trabalho escravo e possuíam uma preocupação implícita de evitar uma revolução ou, no mínimo, uma revolta nacional de escravizados, que poderia colocar em xeque a ordem política e econômica, tal como ocorrera no Haiti (cf. AZEVEDO, 1987), e que, consequentemente, poderia desestabilizar a hegemonia dessas elites dirigentes na organização social, cultural, política e econômica do país. Portanto, não é sem sentido que Joaquim Nabuco, o mais destacado líder abolicionista, afirma que é

no Parlamento e não em fazendas ou quilombos do interior, nem nas ruas e praças das cidades, que se há de ganhar ou perder, a causa da liberdade. Em semelhante lucta, a violência, o crime, o desencadeamento de odios acalentados, só pode ser prejudicial ao lado que tem por si o direito, a justiça, a procuração dos opprimidos [escravizados] e os votos da humanidade. (NABUCO, 1938, p. 26)

Contudo, o posicionamento favorável à abolição da parte dessas elites não pode ser encarado de maneira ingênua, como se pudéssemos definir heróis e vilões; ele está, sim, imerso numa gama de interesses políticos, econômicos e supostamente científicos que irrompem em debates e eventos feitos por atores sociais daquele período, como o Congresso Agrícola realizado em 1878, no Rio de Janeiro (SANTOS, 1977, p. 78-83).

Assim, o processo lento, gradual e seguro da Abolição foi sustentado, entre outros fatores, pela preocupação dessas elites dirigentes em substituir a força de trabalho escravizada pela força livre, fato que pode ser verificado no debate sobre a suposta necessidade de imigração de trabalhadores europeus, momento em que se expõe o quanto a categoria raça era relevante e condicionante nas decisões políticas dessas elites (RAMOS, 1996), até mesmo para o expoente dos abolicionistas, Joaquim Nabuco. Segundo 
esse autor a escravidão havia africanizado o Brasil, ao saturá-lo com o sangue preto, "cheio de vícios", o que "corrompeu" a raça dos brasileiros (NABUCO, 1938, p. 133-134, 196, 244). Para mudar a africanização do Brasil seria necessário, simultaneamente, abolir a escravidão e embranquecer o país, isto é, importar, em massa, imigrantes europeus brancos:

Compare-se com o Brasil actual da escravidão o ideal de Pátria que nós, Abolicionistas, sustentamos: um paiz onde todos sejam livres; onde, atrahida pela franqueza das nossas instituições e pela liberdade do nosso regimento, a immigração européa traga, sem cessar, para os trópicos uma corrente de sangue caucasio vivaz, energico e sadio, que possamos absorver sem perigo, em vez dessa onda chinesa, com que a grande propriedade aspira viciar e corromper ainda mais a nossa raça. (NABUCO, 1938, p. 244)

A preferência por imigrantes europeus em contraponto a imigrantes asiáticos e trabalhadores nacionais e/ou ex-escravizados negros estava associada à crença em raças biologicamente desiguais, isto é, superiores e inferiores, princípio sustentado por teorias da época, como o evolucionismo social e o darwinismo social, conforme demonstrou Schwarcz (1993).

A preocupação supracitada não se manifestou apenas ao âmbito discursivo ou reflexivo. Ela se manifestou e/ou assumiu diversas ações políticas para mudar a composição racial do país. Nossas elites dirigentes procuraram modificá-la através de leis e/ou políticas estatais derivadas das leis, entre outros meios. Por exemplo, por intermédio do Decreto Presidencial no 528, de 28 de junho de 18906, que, por um lado, proibiu a entrada de africanos (negros) e asiáticos (amarelos) no território brasileiro (artigos $1^{\circ}, 2^{\circ} \mathrm{e}$ $\left.3^{\circ}\right)$, e, por outro lado, ajudou a operacionalizar a política de importação de imigrantes europeus brancos, ao estabelecer o pagamento, às companhias marítimas, das passagens dos imigrantes europeus (artigo $7^{\circ}$ ).

Construiu-se, assim, uma política imigratória consistente e/ou sistemática a partir do final do século XIX, que incentivou e impulsionou significativamente a imigração de trabalhadores europeus brancos para formação de um mercado de trabalho livre no Brasil. Como demonstrou

6 Disponível em: <www2.camara.leg.br/legin/fed/decret/1824-1899/decreto-528-28-junho1890-506935-publicacaooriginal-1-pe.html>. Acesso em: 07 dez. 2018. 
Santos (1997, p. 96-97), essa política não possuía apenas objetivo econômico em seu sentido estrito. Este se coadunava com outra intenção explicitada alguns anos antes pelas elites dirigentes brasileiras durante $\circ$ Congresso Agrícola de 1878, qual seja, "embranquecer" a população brasileira. Devemos lembrar que uma das principais comissões que se organizou no e para o referido congresso, a Comissão Nomeada pelos Lavradores de São Paulo (CNLSP), alertava que não era qualquer indivíduo que deveria vir como imigrante para o Brasil para vender a sua força de trabalho e, simultaneamente, ajudar a construir uma nação com "futuro brilhante" nos trópicos. Segundo essa comissão,

Não basta, porém, nem satisfaz o simples resultado de uma immigração abundante. Si o paiz necessita de população estrangeira para desenvolver todas as indústrias e especialmente a agricultura, que é a nossa principal, é, contudo, inquestionável que muito se deve ter em vista a raça, origem, caracter e costumes dos povos que têm de conviver no seio da nacionalidade brasileira, porque antes de tudo precisamos retemperar nossa energia e estimular o trabalho pela moral e pela liberdade. (CNLSP apud SANTOS, 1997, p. 81)

Outros fazendeiros participantes desse congresso não menos importantes, os Representantes de Lavradores de Juiz de Fora e Parayba do Sul (RLJFPS), foram mais explícitos quanto aos trabalhadores que queriam e aos que não queriam trazer para o Brasil. Por um lado, os europeus eram os desejados pelas nossas elites da época, mas não qualquer europeu. Por outro lado, elas repudiavam a vinda de asiáticos (amarelos) e africanos (negros), conforme se pode observar na citação abaixo:

A imigração, como simples fonte de renovação de braços para preencher o déficit deixado pela morte dos trabalhadores actuaes, é por sem dúvida de grande importância; mas na escolha dos immigrantes deve sobretudo preponderar o aperfeiçoamento do trabalho e o progresso na manipulação dos productos agrícolas. Considerado o problema sob este ponto de vista, a origem e índole dos colonos deve influir poderosamente sobre a escolha, e pois não é indiferente que sejam elles asiáticos, africanos ou europeus, e entre os últimos ainda há muito a escolher. (RLJFPS apud SANTOS, 1997, p. 81-82)

Quando se observam esses posicionamentos, desejos e/ou propostas dos principais produtores rurais do país na época, portanto, um dos grupos

Revista Exitus, Santarém/PA, Vol. 10, p. 01-31, e020078, 2020. 
sociais que compunham as nossas elites dirigentes da época, compreendese por que o Decreto 528/1890, supracitado, foi promulgado.

Como resultado, a política imigratória brasileira mudou a composição racial do país em menos de um século, conforme desejava Joaquim Nabuco (1938), fato que se comprova no Quadro 1 abaixo. Nele observa-se que no primeiro Censo Demográfico brasileiro, realizado em 1872, havia no Brasil $61,90 \%$ habitantes não brancos e $38,10 \%$ brancos. No segundo Censo Demográfico, realizado em 1890, já se observa um dos reflexos da política imigratória iniciada por volta de 1870, uma vez que a quantidade da população não branca cai para $56 \%$ e a de brancos aumenta para $44 \%$. No Censo Demográfico de 1940 constata-se que um dos objetivos da política de imigração, qual seja, embranquecer o país, havia sido concretizado, visto que $63,50 \%$ da população residente no Brasil já era branca, 14,60\% preta, $21,20 \%$ parda, $0,60 \%$ amarela e $0,10 \%$ sem declaração de cor/raça, em que pese a porcentagem da população branca vir caindo censo após censo depois do Censo Demográfico de 1940, salvo o Censo de 2000, chegando ao século XXI, isto é, no Censo de 2010, a 47,70\%.

Quadro 1 - População brasileira segundo a cor/raça ao longo dos censos demográficos brasileiros, em porcentagem, - 1872 a 2010

\begin{tabular}{|l|l|r|r|r|r|r|r|}
\hline \multirow{2}{*}{ Ano } & \multirow{2}{*}{ Total } & \multicolumn{7}{|c|}{ Cor/raça } & \multicolumn{1}{l|}{ Sem } \\
\cline { 3 - 7 } & & Branca & Preta & Parda & Amarela & Indígena & Declaração \\
\hline 1872 & $100,0 \%$ & $38,1 \%$ & $19,7 \%$ & $38,3 \%$ & - & $3,9 \%$ & - \\
\hline 1890 & $100,0 \%$ & $44,0 \%$ & $14,6 \%$ & $32,4 \%$ & - & $9,0 \%$ & - \\
\hline 1900 & $100,0 \%$ & - & - & - & - & - & - \\
\hline 1920 & $100,0 \%$ & - & - & - & - & - & - \\
\hline 1940 & $100,0 \%$ & $63,5 \%$ & $14,6 \%$ & $21,2 \%$ & $0,6 \%$ & - & $0,1 \%$ \\
\hline 1950 & $100,0 \%$ & $61,7 \%$ & $11,0 \%$ & $26,5 \%$ & $0,6 \%$ & - & $0,2 \%$ \\
\hline 1960 & $100,0 \%$ & $61,0 \%$ & $8,7 \%$ & $29,5 \%$ & $0,7 \%$ & - & $0,1 \%$ \\
\hline 1970 & $100,0 \%$ & - & - & - & - & - & - \\
\hline 1980 & $100,0 \%$ & $54,2 \%$ & $5,9 \%$ & $38,8 \%$ & $0,6 \%$ & - & $0,4 \%$ \\
\hline 1991 & $100,0 \%$ & $51,6 \%$ & $5,0 \%$ & $42,4 \%$ & $0,4 \%$ & $0,2 \%$ & $0,4 \%$ \\
\hline 2000 & $100,0 \%$ & $53,4 \%$ & $6,1 \%$ & $38,9 \%$ & $0,5 \%$ & $0,4 \%$ & $0,7 \%$ \\
\hline 2010 & $100,0 \%$ & $47,7 \%$ & $7,6 \%$ & $43,1 \%$ & $1,1 \%$ & $0,4 \%$ & $0,0 \%$ \\
\hline
\end{tabular}

Fonte: Petruccelli e IBGE apud Senkevics (2015).

Esses dados nos permitem concluir que o Brasil, ao fim do século XIX, não era um país de maioria branca. Ao contrário, tinha uma população majoritária de pretos, pardos e indígenas (Quadro 1). Como nossas elites dirigentes estavam sob a influência do chamado racismo científico, a 
composição racial do país era uma preocupação para elas (cf. SCHWARCZ, 1993; SANTOS, 1997).

Sob a influência do racismo científico, para a maioria dos integrantes das nossas elites dirigentes, a existência de uma enorme quantidade de população negra e indígena no Brasil, assim como de pessoas fruto de relacionamentos afetivos amorosos e/ou sexuais entre brancos e negros, brancos e indígenas, os chamados mestiços, era sinônimo de degeneração racial, opinião embasada pelo pressuposto de que havia hierarquias entre pessoas de raça branca (considerada superior) e pessoas de raças negra, amarela e indígena (consideradas inferiores), conforme Schwarcz (1993).

Essa autora nos apresenta três teorias consideradas científicas (deterministas) para época, quais sejam, o determinismo geográfico, o evolucionismo social e o darwinismo social, que orientaram a maior parte dos intelectuais brasileiros em suas análises sobre o Brasil. Contudo, ante a brevidade que o espaço exige para produção deste artigo, faremos apenas uma descrição geral das últimas duas teorias?.

Ambas as teorias partem de uma concepção biológica da raça. Nas palavras de Costa (2006, p.153), nessa época "predomina no debate a visão de que as características fenotípicas, reunidas em classificações raciais, definem a priori as capacidades e possibilidades de desenvolvimento pessoal e social". Em outras palavras, caracteres compreendidos como biológicos determinariam caracteres sociais, culturais e psicológicos, entre outros.

Ainda que compartilhem dessa premissa, uma das diferenças significativas entre os adeptos do evolucionismo social e os do darwinismo social está em que os primeiros eram monogenistas e os segundos, poligenistas. Portanto, o evolucionismo social postulava que todos os seres humanos tinham a mesma origem. Mais ainda, embora seu objeto central de análise fosse a cultura dos povos, em seus diferentes estágios de desenvolvimento, os adeptos do evolucionismo social reconheciam também

7 Conhecimentos mais detalhados e profundos sobre essas teorias podem ser vistos em Schwarcz (1993). 
que havia hierarquias raciais e, consequentemente, povos primitivos/inferiores (negros, amarelos e indígenas) e povos civilizados/superiores (brancos). Contudo, havia, por meio dessa maneira de ler o mundo, a possibilidade, mesmo que mínima, de os povos considerados inferiores alcançarem a civilização, isto é, se desenvolverem, passando necessariamente pelos supostos estágios civilizatórios sucessivos:

Civilização e progresso, termos privilegiados da época, foram entendidos não enquanto conceitos específicos de uma determinada sociedade, mas como modelos universais. Segundo os evolucionistas sociais, em todas as partes do mundo a cultura teria se desenvolvido em estados sucessivos, caracterizados por organizações econômicas e sociais específicas. Esses estágios, entendidos como únicos e obrigatórios - já que toda a humanidade deveria passar por eles —, seguiam determinada direção, que ia sempre do mais simples ao mais complexo e diferenciado. (SCHWARCZ, 1993, p. 57)

Para os adeptos do darwinismo social as diferenças entre as raças eram naturais. Eles postulavam que os seres humanos tinham origens diferentes e, por decorrência disso, nasciam desiguais em razão de pertencerem a pelo menos três raças, que eles consideravam as principais: branca, amarela e negra. Essas não deveriam se misturar para não causar degeneração racial e, consequentemente, degeneração social. Por conseguinte, as raças seriam eternamente desiguais, sendo a raça branca a superior:

Denominada "darwinismo social" ou "teoria das raças", essa nova perspectiva via de forma pessimista a miscigenação, já que acreditava que "não se transmitiriam caracteres adquiridos", nem mesmo por meio de um processo de evolução social. Ou seja, as raças constituiriam fenômenos finais, resultados imutáveis, sendo todo cruzamento, por princípio, entendido como erro. As decorrências lógicas desse tipo de postulado eram duas: enaltecer a existência de "tipos puros" - e, portanto, não sujeitos a processo de miscigenação - e compreender a mestiçagem como sinônimo de degeneração não só racial como social. (SCHWARCZ, 1993, p. 58)

Importa ressaltar que essas teorias tinham como locus de produção o continente europeu. Porém, influenciaram sobremaneira as reflexões, os discursos políticos e científicos, assim como as ações de intelectuais, políticos 
e fazendeiros brasileiros, bem como serviram de legitimação do status quo das elites dirigentes antes e após a abolição (COSTA, 2006, p. 151-152).

É preciso salientar, no entanto, conforme defendem Santos (1997) e Costa (2006), que os intelectuais brasileiros não reproduziram de maneira integral as teorias deterministas que aqui chegaram entre o último quartel do século XIX e o início do século XX. Ao contrário, as adaptaram à realidade nacional de maneira tal que fosse possível justificar e sustentar o projeto de "embranquecimento" da população brasileira e, consequentemente, o que se entendia por desenvolvimento e evolução para o país.

Assim, no período supracitado, intelectuais brasileiros de áreas variadas, como Silvio Romero, Joaquim Nabuco, Euclides da Cunha, Monteiro Lobato, entre outros, foram influenciados, a seu modo, pelo que Costa (2006) chamou de "racismo científico". A título de exemplo, citaremos apenas um autor, o cientista político Francisco J. de Oliveira Vianna que, sob influência das teorias racialistas/deterministas, "buscou defender a cientificidade do conceito de raça como chave interpretativa da vida social" brasileira (RAMOS, 2003, p. 574). Não somente isso, Oliveira Vianna afirmou que havia desigualdade e/ou hierarquia entre as raças humanas, sendo a branca a superior e a negra inferior, inclusive quando comparada com a amarela. Segundo ele,

Cabe observar, porém, que, entre os antropologistas e etnólogos, mesmo os que admitem a igualdade das raças, só a admitem em relação às raças brancas, quando comparadas entre si. Na sua quase maioria, porém, estes cientistas recusam-se a aceitar o princípio da igualdade das raças brancas com as demais raças do globo, especialmente com a raça negra. (...) não sou de modo algum partidário da igualdade das raças. Nem creio que, em face das modernas teorias biotipológicas, seja possível mais admitir-se esta concepção igualitarista. (OLIVEIRA VIANNA, 1959, p. 176-177)

Deve-se lembrar de que a província de São Paulo, à época, desponta como uma região econômica e politicamente protagonista das discussões acima mencionadas, particularmente pelo boom do ciclo do café nesse período. Tais discussões chegaram à Assembleia Legislativa desse Estado, assim como ao Congresso Nacional brasileiro (cf. SANTOS, 1997). Quanto aos 
debates no parlamento paulista sobre que tipo de trabalhador o país deveria ter após a abolição, deve-se frisar que nessa instituição não somente o discurso pró-imigração de europeus foi avassalador bem como o discurso contra os negros e/ou africanos era uma constante, como se pode observar, por exemplo, na exposição do deputado estadual Paula Souza, na sessão de 15 de fevereiro de 1884. Segundo o parlamentar,

Se ao negro devemos a nossa civilisação relativa, ao negro também devemos as nossas difficuldades acttuaes. (...) Discute-se a questão de falta de braços, o paulista entendeu que o negro já era innopportuno, não podia mais ser tolerado na província, ao lado dos nossos fóros de povo civilisado, das nossas condições de adiantamento moral e christão, fechou sua porta, e disse - não entra mais negro nenhum. Quis-se abrir algumas frestas por meio de excepções; mas a assembléa levantou-se e disse - Não, a lei é absoluta, não entra mais negro (PAULA SOUZA apud SANTOS, 1997, p. 90-91).

Nesse sentido, a política de imigração racista e racialista mencionada acima teve um papel central na e para a formação do mercado de trabalho livre em São Paulo e, consequentemente, na mudança da composição racial do país. Essa política impôs medidas discriminatórias contra trabalhadores/as negros/as, ao barrar a entrada de escravizados e ex-escravizados na Província, ao mesmo tempo que propiciou o surgimento de políticas estatais favoráveis à entrada de imigrantes europeus. Segundo Santos,

Para dirimir as dúvidas de que a política imigratória adotada pelos governos federal e paulista, além de ter o objetivo patente de formação de um mercado de trabalho livre no Estado de São Paulo, cumpriu também o desígnio de embranquecer as populações paulista e brasileira, parece-me relevante comparar a quantidade de africanos que foram traficados como escravos para $\circ$ Brasil durante aproximadamente trezentos anos, da metade do século XVI até a metade do século XIX, com a quantidade de imigrantes importados em sua maioria da Europa durante oitenta e sete anos, de 1851 a 1937, para se verificar como realmente o desejo do deputado paulista Paula Souza foi completamente saciado. Enquanto naquele primeiro período entraram de 3.500 .000 a 3.600.000 negros africanos no país, nesse último breve intervalo de tempo, isto é, em menos de cem anos, entraram 4.793.981 imigrantes, sendo que só o Estado de São Paulo ficou com 50,42\% desses imigrantes, ou seja, 2.417.386 estrangeiros. Em outras palavras, em menos de um século de política imigratória subsidiada pelo governo brasileiro importou-se mais força de trabalho (brancos livres), 
do que em três séculos de tráfico de escravos (negros cativos). (SANTOS, 1997, p. 95-96)

Esses números corroboram o desejo de Joqquim Nabuco e/ou o objetivo das nossas elites dirigentes de "embranquecer" a população brasileira, indicando sua atuação vigorosa através de vias políticas, econômicas e intelectuais racialmente orientadas para concretização desse objetivo.

Coincidência ou não, Luís Gama viveu a maior parte de sua vida na província de São Paulo. Ainda que tenha falecido em 1882, pouco tempo antes da última lei que garantiu o processo lento, gradual e seguro da abolição no Brasil. Esse abolicionista e advogado negro esteve ativamente ligado a esse mesmo processo, mas a partir de uma abordagem distinta daquela ansiada por Joaquim Nabuco e pelas elites dirigentes descritas acima, como mostraremos a seguir.

\section{A via parlamentar de Joaquim Nabuco}

Como aponta Stuart Hall (2005, p. 52), a constituição de uma identidade nacional é marcada por três elementos fundamentais, entre os quais um deles é a construção de uma narrativa sobre o passado e sobre as personagens históricas que embasam a identidade de uma nação. Sobre o Brasil, por exemplo, não é possível deixarmos de mencionar personalidades que sustentam aquilo que Hall (2005) chama de identidade nacional: as figuras dos Bandeirantes, Tiradentes, Getúlio Vargas, entre outras, que nos são apresentadas desde a infância, tanto em currículos escolares quanto em feriados e rituais seculares que atualizam a versão de uma narrativa sobre a nação. Em relação ao período da abolição, contexto que nos interessa em particular, a personalidade de Joaquim Nabuco parece ter sido institucionalizada como principal símbolo da luta contra a escravidão (CARDOSO, 1995, p. 27), sendo transformado em um herói por sua luta antiescravista e, consequentemente, componente importante de uma identidade nacional brasileira. 
É preciso questionar, contudo, o quanto a figura de Joaquim Nabuco como símbolo nacional se distingue de seus posicionamentos e ações políticas concretas, localizadas em seu tempo histórico. Essa distinção entre o símbolo heroico e a personagem histórica pode ser verificada naquilo que conceituamos como "projeto de abolição", nesse caso, o projeto levado adiante por Nabuco. No entanto, antes de expor seus posicionamentos específicos sobre esse assunto, importa mencionar parte do pensamento ideológico e intelectual por trás dessas posições do clássico abolicionista.

Em um primeiro momento, é preciso deslocar a figura de Joaquim Nabuco de sua posição mítica para sua posição histórica, situando-o como pessoa de seu tempo e, portanto, associado a determinadas concepções historicamente localizadas em termos científicos e filosóficos, como é o caso da questão racial. Suas ideias não se distinguem, de modo radical, das concepções concernentes às teorias deterministas e do racismo científico discutidos brevemente na sessão anterior. Sua concepção, assim como a de outros intelectuais, pressupõe a raça em uma dimensão biológica (SANTOS, 1997, p. 84). Essa compreensão carregará consigo uma noção de hierarquia entre raças, assumindo algumas como "superiores", como a branca, e outras como "inferiores", como a amarela e a negra. Em suas próprias palavras:

O negro e o branco, vivendo misturados socialmente durante
séculos, o sangue preto naturalmente tenderá a ser eliminado no
sangue branco, ou desaparecer, cedendo essa raça o campo a
outra mais preparada para a luta da vida, porque (...) o negro tem a
alimentação abundante do selvagem, tem a mesma
despreocupação do dia seguinte, e não aprendeu a preparar-se
para ele senão no regime de descuido pessoal, de abandono, de
confiança nos outros, que se chama escravidão. (NABUCO, 1938, p.
182)

Essa proposição não evidencia apenas a crença em raças superiores e inferiores, mas também se associa ao projeto de embranquecimento já discutido e expõe o modo pelo qual as teorias deterministas advindas da Europa eram adaptadas à realidade brasileira, como é o caso de ressignificar a miscigenação, metamorfoseando-a de um aspecto negativo para positivo, como se viu na citação acima. $O$ projeto de 
embranquecimento influencia de modo fundamental as concepções de Nabuco sobre a abolição e sobre a política imigratória racialista ao fim do século XIX. Conforme Santos,

Nabuco acreditava que a escravidão desvalorizava o trabalhador e inibia a vinda de imigrantes europeus para o Brasil, o que retardava o processo de embranquecimento do país (...). Portanto, a escravidão era um mal não só porque havia africanizado o Brasil, mas, também, porque retardava o progresso brasileiro, ao impedir a chegada da civilização e da modernidade através da imigração europeia e da população branca. (SANTOS, 1997, p. 84)

Não se trata de qualificar com juízo de valor as posições políticas e ideológicas de Nabuco, mas considerar o quanto essas são fruto do contexto histórico e sociocultural em que o autor estava inserido. Em Nabuco, a representação de seu pensamento e suas ações políticas estão diretamente associadas aos ideais das elites dirigentes de sua época. Essa influência se mostra de maneira direta em suas concepções sobre o modo pelo qual o processo de abolição deveria ocorrer. Segundo o próprio Nabuco:

\begin{abstract}
A propaganda abolicionista, com efeito, não se dirige aos escravos. Seria uma covardia, inepta e criminosa, e, além disso, um suicídio político para o partido abolicionista, incitar à insurreição, ou ao crime, homens sem defesa, e que a Lei de Lynch, ou a justiça pública, imediatamente haveria de esmagar (...). A escravidão não há de ser suprimida no Brasil por uma guerra civil, muito menos por insurreições ou atentados locais. Não deve ser, tampouco, por uma guerra civil, como o foi nos Estados Unidos (...). A emancipação há de ser feita, entre nós, por uma lei que tenha os requisitos externos e internos de todas as outras. É, assim, no Parlamento e não em fazendas ou quilombos do interior, nem nas ruas e praças das cidades, que se há de ganhar ou perder a causa da liberdade (...). Não é aos escravos que falamos, é aos livres: em relação àqueles fizemos divisa das palavras de Sir Walter Scott: "Não acorde o escravo que dorme, ele sonha talvez que é livre". (NABUCO, 1938, p. 24-31)
\end{abstract}

Em suma, as principais características do projeto de abolição proposto por Nabuco não se distinguem, em suas principais premissas, daquele das elites dirigentes do período, até porque este intelectual era um dos membros orgânicos dessas elites. Assim, para Nabuco, o processo deveria ocorrer por via parlamentar, afastando-se de uma insurreição popular, sem controle dos de cima e/ou das instituições. Para Nabuco, ao contrário, os acontecimentos 
deveriam ser conduzidos institucionalmente, de maneira lenta, gradual e segura. Segundo suas próprias palavras, a abolição sustentada pelos parlamentares abolicionistas se dirige aos livres e não aos escravizados.

As reflexões e proposições expostas por Nabuco nos permitem afirmar que seu projeto de abolição não era emancipatório em sentido amplo e profundo, ou seja, pleno para os/as negros/as escravizados/as, visto que estava atrelado e/ou fundamentado, direta ou indiretamente, às teorias deterministas (e racistas) incorporadas e utilizadas pelas elites dirigentes brasileiras do final do século XIX e o início do século XX, para mudar o nosso país em sentido amplo.

Antes de ser uma ação humanitária, a luta de Joaquim Nabuco contra a escravidão objetivava embranquecer $\circ$ Brasil por meio da eliminação física e simbólica, entre outras, dos/as negros/as que foram transplantados/as do continente africano para o Brasil. Em última instância, Nabuco comungava com o objetivo das nossas elites dirigentes de construir nos trópicos uma nação com futuro promissor, isto é, branca. O desejo e/ou seu pressuposto da eliminação física dos/as negros/as pode ser observado na tese de que o sangue preto seria eliminado pelo sangue branco, citada anteriormente. Já a eliminação simbólica pode ser observada quando da morte do escritor Machado de Assis, um dos fundadores da Academia Brasileira de Letras ( $A B L$ ). Na época, o escritor José Veríssimo escreveu um artigo elogiando Machado e o identificando racialmente como um mulato. Nabuco não aceita essa identificação racial, suplica a Veríssimo que a retire e, mais que isso, busca embranquecer Machado de Assis. Conforme o próprio Joaquim Nabuco,

A morte do Machado me faz inveja, comparada com a que posso ter no estrangeiro. - Seu artigo no Jornal está belíssimo, mas esta frase causou-me arrepio: "mulato, foi de fato um grego da melhor época". Eu não teria chamado o Machado de mulato e penso que nada lhe doeria mais do que esta síntese. Rogo-lhe que tire isso, quando reduzir os artigos a páginas permanentes. A palavra não é literária e é pejorativa, basta ver-lhe a etimologia. Nem sei si alguma vez ele a escreveu e que tom lhe deu. O Machado para mim era um branco, e creio que por tal se tomava; quando houvesse sangue estranho, isto em nada afetava a sua perfeita caracterização caucásica. Eu pelo menos só vi nele o grego. O nosso pobre amigo,

Revista Exitus, Santarém/PA, Vol. 10, p. 01-31, e020078, 2020. 
tão sensível, preferia o esquecimento á gloria com a devassa sobre suas origens. (NABUCO, 1931, p. 387-388)

Reconhecer a genialidade de Machado de Assis não era um problema para Nabuco. Ao que parece, o problema era admitir que um ascendente de africanos fosse tão genial e, mais do que isso, ser uma personalidade (negra) emblemática, um exemplo, às gerações presentes e futuras, negras ou não, de que os/as negros/as eram e podem ser tão brilhantes quanto os/as brancos/as, assim como seriam e foram capazes de construir o futuro brilhante de uma nação nos trópicos.

Ao embranquecer simbolicamente Machado de Assis, Nabuco estava seguindo à risca um dos seus princípios ou conduta de vida, já citado anteriormente: o de não acordar os escravizados (negros) que dormem, pois estes poderiam sonhar que eram livres, o que implicaria não enxergar obstáculos insuperáveis para realizar suas aspirações, sonhos e, até mesmo, de permanecerem vivos e se orgulharem de sua origem racial, sem necessariamente ter que menosprezar, estigmatizar e/ou discriminar outras identidades raciais.

Em suma, o projeto de abolição de Nabuco tinha como objetivo último um ideal de desenvolvimento e progresso de país a partir de uma visão racializada e racista própria das elites dirigentes nacionais, do qual Nabuco era um dos representantes e um dos seus principais expoentes intelectuais.

\section{Luís Gama e a insurgência como ideal abolicionista}

A trajetória de Luís Gonzaga Pinto da Gama, nascido em 1830, ou seja, em plena sociedade escravista, assemelha-se a uma narrativa literária do fim de século XIX para o início do XX, conforme discussão já indicada no início do texto. Essa trajetória é refletida em sua obra poética e em seus posicionamentos políticos. No âmbito dessa trajetória há pelo menos um fato determinante e/ou divisor de águas, qual seja, aprender a ler e escrever aos 17 anos de idade. Após isso, Luís Gama descobre documentos sólidos que 
comprovam a ilegalidade de sua escravização. Imediatamente foge da casa do seu senhor e conquista a sua liberdade. Conforme revela o próprio Luís Gama, em carta enviada a Lúcio de Mendonça,

Em 1848, sabendo eu ler e contar alguma cousa, e tendo obtido ardilosa e secretamente provas inconcussas de minha liberdade, retirei-me, fugindo, da casa do alferes Antônio Pereira Cardoso, que aliás votava-me a maior estima, e fui assentar praça. Servi até 1854, seis anos; cheguei a cabo de esquadra graduado, e tive baixa de serviço, depois de responder a conselho, por ato de suposta insubordinação, quando tinha-me limitado a ameaçar um oficial insolente, que me havia insultado e que soube conter-se (GAMA, 2005, p. 169-170).

Ainda que não seja nosso objetivo aqui tentar empreender uma análise detalhada dessa carta, como a feita por Molina (2018), não podemos deixar de enunciar as ações de Luís Gama contra injustiças de todas as ordens, como, por exemplo, se rebelar contra a sua própria escravização e fugir dessa condição, assim como se insurgir contra um oficial do exército, característica que parece ser uma missão de vida para esse abolicionista, visto que continuou a lutar de todas as formas contra a escravidão até sua morte. Conforme nos informa o historiador e sociólogo Clóvis Moura, Luís Gama:

Dedicou-se a defender escravos na Corte de Justiça e frequentemente ocultou em sua casa negros fugidos, a quem ajudava a escapar à perseguição de seus senhores. Já em 1870, argumentava, em defesa de um negro que matara o seu senhor, que todo escravo que mata o seu senhor pratica um ato de legítima defesa. Essa opinião pouco ortodoxa só poderia criar contra ele a ira dos escravistas mais empedernidos. (MOURA, 2005, p. 168)

Como se pode observar, esta era uma atitude completamente diferente e até mesmo divergente da adotada por Joaquim Nabuco, que defendia os/as escravizados/as distanciado deles/as, no parlamento; portanto, sem contato visual, emocional-afetivo, entre outros, com os/as escravizados/as. Nabuco também não admitia ações violentas para pôr fim à escravidão, como visto anteriormente. Diferentemente, Luís Gama agia diretamente na Corte de Justiça, olhando nos olhos dos/as escravizados/as, compartilhando suas emoções, dores, sofrimentos, humilhações e sonhos de 
liberdade, assim como defendia o uso da violência para pôr fim à escravidão, conforme visto na citação de Moura (2005). Ao que tudo indica (mas com as devidas ponderações), Luís Gama portava de forma consistente, e quem sabe até mais radicalmente, o que Santos denominou de ética da convicção antirracismo ${ }^{8}$. Esta

\begin{abstract}
é o preceito e/ou valor moral de não se resignar com o preconceito e a discriminação raciais, bem como com as consequências destes, tais como as desigualdades raciais, a inferiorização de indivíduos ou grupos sociorraciais, entre outras. Ou seja, em última instância, ética da convicção antirracismo é o preceito de lutar contra o racismo em qualquer esfera da vida social, seja na rua ou no trabalho, na escola ou na universidade, na vida pública ou privada, entre outros espaços (...). (SANTOS, 2014, p. 244).
\end{abstract}

Devemos enfatizar que visamos, por meio da citação de Luís Gama, tão somente enunciar que é plausível vislumbrar que irrompem, após o divisor de águas supracitado, dois momentos de sua biografia: um como negro escravizado e um como negro intelectual (cf. SANTOS, 2014) não se possa dizer que houve uma ruptura em relação aos seus posicionamentos anteriores, bem como em relação às suas ações políticas, que já eram contrárias à escravidão. Em realidade, Luís Gama seguia os passos de sua mãe, a militante negra antiescravidão Luísa Mahin, embora não tenha mais convivido com ela desde que foi vendido pelo próprio pai, como escravo, em 1840 (cf. MOURA, 2005). Assim, ao contrário de uma ruptura, é possível argumentar que há uma influência de sua condição de ex-escravizado não escolarizado em sua posterior condição de homem livre

\footnotetext{
8 Santos (2014) adaptou esse termo de Max Weber a partir da análise que fez da ação de um grupo específico de negros/as: aqueles/as que eram ativistas dos movimentos sociais negros (entre a década de 1970 e o início da década de 2010) e que, simultaneamente, ingressaram em programas de pós-graduação stricto sensu para ampliarem (acadêmicocientificamente) os seus conhecimentos sobre o racismo no Brasil. Observa-se assim que a construção do termo "ética da convicção antirracismo" está situada na virada do século XX para o século XXI. Portanto, tem a ver com cidadãos que vivem em uma sociedade formalmente livre e democrática, onde o racismo é considerado crime. Porém, o nosso sujeito-"objeto" de estudo, Luís Gama, situa-se, principalmente, a partir da segunda metade do século XIX, numa sociedade escravista e racista formalmente. Mesmo assim pensamos ser plausivel dizer que Luís Gama portava uma determinada ética da convicção antirracismo, visto que ele fazia uso, simultaneamente, da experiência de ativista e do conhecimento intelectual para operacionalizar a luta antirracismo.

9 Guimarães (2004) classifica Luís Gama como intelectual negro. Nós o denominamos de negro intelectual, conforme definição de Santos (2014, p. 265-266).
} 
e letrado e/ou intelectual engajado, levando-o inclusive a se dedicar mais plena e intensamente à luta contra a escravidão após aprender a ler e escrever e se apropriar brilhantemente da racionalidade jurídica.

A propósito, Santos (2014) argumenta que a educação já era um valor fundamental para a população negra desde o fim do século XIX, valor que foi incorporado e ensinado pelos movimentos sociais negros brasileiros ao longo de todo o século XX e que ainda continua sendo considerado imprescindível nessas primeiras décadas do século XXI. Para esses movimentos, a educação é um dos dispositivos sociais que torna possível a ascensão social e, concomitantemente, pode ser usada como um poderoso instrumento contra o racismo. Instrumento que os próprios negros podem e devem usar na luta por liberdade, justiça e igualdade racial, como o fez Luís Gama.

Portanto, Luís Gama (e/ou sua trajetória) poderia ser considerado um exemplo típico da operacionalização de tal dispositivo de resistência e/ou de sua eficiência. Mas, mais do que isso, ele representa esse ideal como símbolo já em meados do século XIX, dado que, em virtude de uma formação praticamente autodidata, o autor ascende socialmente $e$ mobiliza as suas condições de não escravizado, abolicionista e detentor de conhecimento nos campos artístico (como poeta) e jurídico (como advogado) em prol dos/as escravizados/as e/ou injustiçados/as. Portanto, Luís Gama agia organicamente, como negro intelectual (cf. SANTOS, 2014), Iutando pelos ideais de seu grupo racial de pertença.

Como demonstrou Santos (2014), se os negros intelectuais não separam a sua atividade militante nos movimentos sociais negros de suas atividades acadêmico-intelectuais, Luís Gama, no século XIX, não separava a sua atuação como advogado e como poeta da sua luta antirracista. Ao contrário, há uma interação e/ou relação direta e explícita entre atividades intelectuais e ação política. Por exemplo, em sua obra poética, o autor se posiciona e se reconhece como pessoa negra, reafirmando e questionando as discriminação e desigualdade raciais, bem como todas as injustiças existentes em sua realidade social. O trecho abaixo, de um de seus poemas, 
explicita um posicionamento político ácido e irônico, tendo a questão racial como centro da discussão:

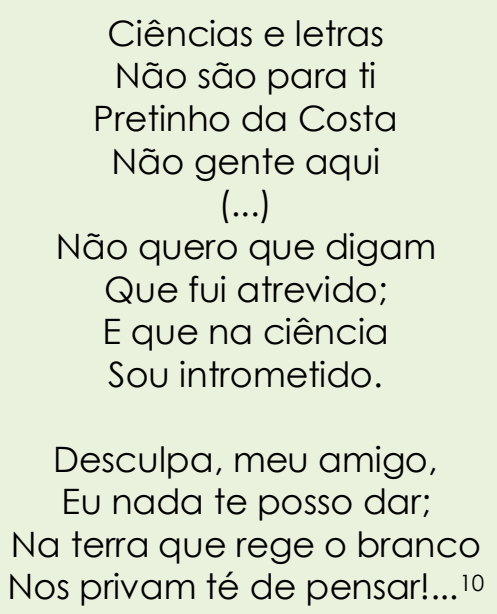

Esse trecho aponta para a relação entre consciência racial, educação e intelectualidade, assim como para compreensão de que de há limitações sociais, políticas, econômicas, jurídicas, educacionais, entre outras, para os/as negros/as numa sociedade em que os/as brancos/as comandam fundamentados na ideia da existência de hierarquia de raças. Esse discernimento, entre outros fatores vistos ao longo do texto, nos habilita a considerar Luís Gama como um negro intelectual, um sujeito que "lê a realidade social" em que está inserido levando em consideração a sua identidade racial e o significado dessa num sistema escravista-racista; ele compreende a construção estigmatizada dessa identidade, ou melhor, compreende aquilo que é atribuído a ele le ao seu grupo racial de pertença) pela raça dominante" "; resiste e luta com todos os meios que the são possíveis, inclusive a poesia e a racionalidade jurídica, contra o sistema que possibilitou o surgimento dessa identidade estigmatizada e tudo o que ela significa para os/as opressores/as e para parte dos/as oprimidos/as, aqueles/as que incorporaram a visão de mundo dos/as opressores/as e

\footnotetext{
10GAMA, Luís. No álbum do meu amigo J. A. da Silva Sobral. In: Primeiras Trovas Burlescas de Getulino. Disponível em: <https://www.literaturabrasileira.ufsc.br/_documents/000600867.html>. Acesso em: 20 dez. 2018.

11 A expressão "raça dominante" foi utilizada por Florestan Fernandes (1972) para se referir aos/às brancos/as.
} 
declaram e/ou demonstram lealdade aos valores e interesses da raça dominante.

Luís Gama, apesar de ter conquistado dispositivos sociais nesse sistema, como a educação e intelectualidade, e ter ascendido socialmente, não aderiu aos valores opressores da raça dominante. Ao contrário, ele recusa e se contrapõe veementemente à lealdade subserviente, assumindo uma posição ativa quanto à constituição das relações entre brancos (livres) e negros (escravizados e livres) no século XIX, ao mesmo tempo em que denuncia, questiona e se insurge contra o sistema escravista e as instituições que the dão sustentação, incentivando a população negra a se voltar contra as condições opressoras que Ihe assolavam. Para Shirley Ferreira, Luís Gama seria o precursor de uma literatura negra brasileira, ao assumir essa posição de agente e sujeito a favor da população negra escravizada e livre da sua época, o que aponta para sua condição de negro intelectual, como temos indicado.

No âmbito da escravidão, seu enredo poético não se identificava com o lamento e o pessimismo, mas sim com a superação daquele estado de coisas. Tendo como alvo o sistema escravocrata, ele adota um discurso crítico, incluindo aqueles personagens que se beneficiavam da mão de obra escrava. (...). Foi considerado assim precursor de uma literatura que de fato só se consolidaria entre nós no final do século XX: a literatura negra brasileira (FERREIRA, 2017, p. 28).

Nesse mesmo caminho, a obra poética de Luís Gama se distingue de outros poetas desse mesmo período, mesmo entre aqueles que pautam as condições de escravização da população negra. Essa distinção se sustenta na medida em que Luís Gama toma para si, como missão de vida, um caráter de representante dos negros escravizados, ele mesmo na condição de ex-escravizado, ao buscar metamorfosear a condição de subalternização dos negros para uma representação positiva, qual seja, os negros enquanto agentes e sujeitos ativos, como indica Ferreira.

Valendo-se da sátira como um modo de despertar o orgulho dos negros em torno de sua própria gente, Luís Gama sabia o que estava fazendo. O processo de escravidão havia inibido a capacidade de os negros se reconhecerem como seres humanos livres, igualmente

Revista Exitus, Santarém/PA, Vol. 10, p. 01-31, e020078, 2020. 
portadores de direitos. Assim, a imagem positiva do negro presente nos poemas serviria como uma fonte de inspiração a outros escritores negros. Sobretudo porque, entre estes, havia um pretenso anseio de branquitude (FERREIRA, 2017, p. 56-57)

Sua distinção como negro intelectual, contudo, se dá em um contexto em que não havia uma participação substantativa, assim com uma articulação explícita de parte da população negra em círculos de intelectuais como em Programas de Pós-graduação stricto sensu, como discutida por Santos (2014). Nesse sentido, sua presença em círculos intelectuais brancos, em face de suas posições políticas quanto às relações raciais, era peculiar. Ao mesmo tempo em que era aceito como intelectual, sua condição de negro e sua militância antiescravismo/racismo reafirmam sua posição como um negro intelectual no mundo artístico-intelectual dos brancos:

Seus versos expunham o preconceito que havia no mundo dos intelectuais brancos do oitocentismo literário, mesmo entre aqueles que pertenciam aos círculos abolicionistas. Em razão do posicionamento radical a respeito da libertação dos escravos, ele acumulou alguns desafetos entre seus pares. Até certo ponto, a sua participação em círculos que discutiam o processo escravocrata era aceita em razão do sucesso que ele tinha nos tribunais, ganhando casos a favor da soltura de escravos. Nas entrelinhas, porém, era tido como um "intrometido" - um sujeito que estava ocupando um lugar que de fato não lhe pertencia (FERREIRA, 2017, p. 62).

Em outros de seus poemas, Luís Gama apresenta-se de maneira irônica e sarcástica frente aos grupos e às instituições sociais de sua época, legando sua característica estilística satírica a Gregório de Matos, como defende Laranjeira (2010). No trecho do poema abaixo, assim como em todas as estrofes do texto, Luís Gama ironiza desde o Império até as faculdades da época, passando por políticos e intelectuais:

Se impera no Brasil o patronato, Fazendo que o Camelo seja Gato, Levando o seu domínio a ponto tal,

Que torna em sapiente o animal; Se deslustram honrosos pergaminhos Patetas que nem servem p'ra meirinhos

E que sendo formados Bacharéis, Sabem menos do que pecos bedéis: Não te espantes, ó Leitor, da novidade, 
Pois que tudo no Brasil é raridade! 12

De modo semelhante, a sua atuação como advogado não se desvia de uma trajetória de resistência e luta contra a opressão racial-escravista, ao contrário. Portanto, não é sem motivo sua alcunha de "advogado dos escravos", já que defendeu o direito à liberdade, através da alforria, a mais de quinhentos escravizados/as, fato que o próprio Luís Gama enuncia em carta que enviou a Lúcio Mendonça ${ }^{13}$, como visto anteriormente. Como expõe Maria Luiza Ferreira de Oliveira, Luís Gama

Marcava presença, acusando juízes, pontuando injustiças, como no episódio ocorrido em uma cidade do interior, quando, após matarem seu senhor, quatro escravos foram linchados no caminho da delegacia, e Luís Gama declarou: "(...) o escravo que mata o senhor, que cumpre uma prescrição inevitável do direito natural, e o povo indigno, que assassina heróis, jamais se confundirão" (OLIVEIRA, 2010, p. 3)

É plausível afirmar que os irreverentes e mais que ousados posicionamentos de Luís Gama, segundo os fatos e argumentos que apresentamos aqui, podem derivar de duas características: 1) sua posição como um negro intelectual ex-escravizado que não aceita a escravização dos seres humanos; e 2) sua aberta militância como republicano radical. Essas duas características, seus pressupostos e os consequentes posicionamentos delas derivados, possibilitam a Luís Gama uma distinta formulação do projeto de abolição (hegemônico), ou seja, o defendido por Joaquim Nabuco e/ou as elites dirigentes brasileiras da época.

Diferentemente do processo requerido por parte das elites (brancas) dirigentes, que defendia a abolição, de modo que fosse lenta, gradual e segura, Luís Gama defendia a posição de que os/as escravizados/as deveriam revoltar-se contra a ordem social vigente à época (FERREIRA, 2007;

12 GAMA, Luís. Sortimento de Gorras (para gente de grande tom). In: Primeiras Trovas Burlescas de Getulino. Disponível em: <https://www.literaturabrasileira.ufsc.br/_documents/0006-00867.html>. Acesso em: 20 dez. 2018.

13 Luís Gama era um rábula, ou seja, um advogado não diplomado. Seu reconhecimento jurídico como advogado foi feito pela $O A B$ somente em 2015, 133 anos após sua morte (VEIGA, 2017). Esse fato associa-se a nossa discussão sobre o estabelecimento de um cânone clássico e de personagens históricas envolvidas em uma narrativa de identidade nacional. 
NUNOMURA, 2014), organizando-se como grupo político revolucionário. Seu projeto de abolição, portanto, é diametralmente oposto ao de Joaquim Nabuco, pois desloca a deliberação (sobre abolição) dos parlamentares para os/as próprios/as escravizados/as. Se Nabuco afirma que seu projeto não é direcionado aos escravizados, mas aos livres, o projeto de Luís Gama era direcionado e deveria ser protagonizado pelos/as próprios/as escravizados/as. Mais que isso, esses/as deveriam ser indenizados/as por terem sido privados de liberdade e submetidos/as a trabalhos forçados. Essa tensão nos projetos de abolição manifesta-se no âmbito do próprio Partido Republicado, sendo Luís Gama um representante da ala radical:

Examinando mais de perto a vida de Luís Gama, percebemos a coerência da sua posição política, pois ele não era de se calar diante dos ranços racistas que teimavam em prosperar dentro do Movimento Abolicionista e do Partido Republicano. O que se pode apurar, examinando os seus discursos mais inflamados, é que ele defendia o seu posicionamento antiescravista dentro da ala mais radical do partido. A libertação dos escravos era uma urgência; além disso, ele defendia que os negros libertos fossem indenizados como um modo de compensar o processo de marginalização a que foram submetidos. (FERREIRA, 2017, p. 60)

Ainda que tenha ascendido socialmente pelo fato de ter conquistado a liberdade, ter aprendido a ler e escrever e, mais que isso, ter aprendido a racionalidade jurídica e saber operacionalizá-la como poucos de sua época, tendo atuado e trabalhado em espaços teoricamente exclusivos a representantes das elites dirigentes brancas, Luís Gama não colaborou com o sistema escravista. Ao contrário, transformou-se em um intelectual orgânico (cf. GRAMSCl, 1982) dos/as escravizados/as. Dessa forma, lutou contra esse sistema e suas opressões em todos os espaços que pôde. As características de seu projeto de abolição associam-se a fatos biográficos e aos fenômenos sociológicos que dele derivam, assim como estavam ancoradas no firme compromisso e/ou lealdade aos membros do seu grupo racial de pertença. 


\section{Considerações finais}

O argumento que se pretendeu sustentar ao longo do texto possui limitações metodológicas, particularmente em seu aspecto empírico de produção de dados. Acreditamos, no entanto, que as discussões e os exemplos aqui apresentados nos permitem observar projetos de abolição distintos e até divergentes, respectivamente, de Joaquim Nabuco e Luís Gama. Mais ainda, a ideia de projeto de abolição como categoria analítica para organização dos valores e ideais de Joaquim Nabuco e de Luís Gama se demonstrou profícua.

Devemos destacar que por meio deste texto nos esforçamos para trabalhar uma contextualização histórica do período anterior à Abolição e posicionar sociologicamente dois atores sociais (cf. TOURAINE, 1994), compreendidos como intelectuais orgânicos (cf. GRAMSCl, 1982) e representantes de duas classes antagônicas da época: a classe de senhores/as (brancos/as) e/ou das elites dirigentes daquela sociedade e a classe dos/as escravizados/as (negros/as).

Para pesquisas posteriores, pensamos que seria relevante verificar 0 quanto cada um dos dois projetos de abolição supracitados, que não eram defendidos apenas por Joaquim Nabuco e Luís Gama, exerceram influência concreta na vida social daquele período, agregando à discussão as noções de hegemonia e revolução passiva, também discutidas por Gramsci (1982). A possibilidade de compreender o projeto de abolição de Nabuco como a concretização de uma revolução passiva e o projeto de abolição de Gama como um discurso contra-hegemônico enriqueceria a dimensão política e sociológica de dois projetos (ou mais) de abolição em disputa histórica. No entanto, como mencionamos, a figura de Joaquim Nabuco foi política e simbolicamente agregada à identidade nacional (HALL, 2005) e a figura de Gama, tanto em uma narrativa sobre o passado quanto em um cânone literário, parece ter sido marginalizada, lamentavelmente, em currículos escolares e universitários. Contudo, pensamos que novas pesquisas e/ou estudos, impulsionados pelas determinações da Lei 1 1.645/2008, poderão dar 
visibilidade e reconhecimento a um dos maiores abolicionistas que o Brasil já teve, Luís Gama, e ao seu projeto de abolição, "de baixo para cima", que se opôs ao projeto de "de cima para baixo", de Joaquim Nabuco.

\section{Referências}

AZEVEDO, C. M. M. Onda negra medo branco. O negro no imaginário das elites - século XIX. Rio de janeiro: Paz e Terra, 1987.

BERND, Z. O que é negritude. São Paulo: Brasiliense, 1988.

CARDOSO, F. H. Pensadores que Inventaram o Brasil. São Paulo: Companhia das Letras, 2013.

CARDOSO, F. H. Discurso de posse no Congresso Nacional. In Brasil.

Presidência da República. Brasília: Biblioteca da Presidência da República, 1995.

CARDOSO, F. H. Condições sociais da industrialização de São Paulo. Revista Brasiliense. São Paulo: no 28,1960.

COSTA, S. Dois Atlânticos: teoria social, anti-racismo, cosmopolitismo. Belo Horizonte: Editora da UFMG, 2006.

EISENBERG, P. L. A mentalidade dos fazendeiros no Congresso Agrícola de 1878. In: LAPA, J. R. A. (Org.). Modos de produção e realidade brasileira. Petrópolis: Vozes, 1980.

FERNANDES, F. A integração do negro na sociedade de classes. $3^{a}$ ed. São Paulo: Ática, 2 vols. 1978.

FERNANDES, F. O Negro no mundo dos brancos. São Paulo: Difusão Europeia do Livro, 1972.

FERNANDES, F; BASTIDE, R. Relações raciais entre negros e brancos em São Paulo: ensaio sociológico sobre as origens, as manifestações e os efeitos do preconceito de cor no município de São Paulo. São Paulo: Anhembi. 1955.

FERREIRA, L. F. Luís Gama: um abolicionista leitor de Renan. Estudos Avançados, v. 21, n. 60, p. 271-288, 2007.

FERREIRA, S. Luís Gama e a identidade negra na literatura. Juiz de Fora: Editora do autor, 2017.

GAMA, L. G.P. Carta Autobiográfica a Lúcio de Mendonça, de 25 de julho de 1880. In: MOURA, C. Dicionário da Escravidão Negra no Brasil. São Paulo: Edusp, 2005. 
GRAMSCl, A. Os intelectuais e a organização da cultura. Rio de Janeiro: Civilização Brasileira, 1982.

GUIMARÃES, A. S. A. Intelectuais negros e formas de integração nacional. Estudos Avançados, v. 18, n. 50, p. 271-284, 2004.

HALL, S. A identidade cultural na pós-modernidade. Rio de janeiro: DP\&A, 2005.

IANNI, O. Raças e classes sociais no Brasil. Rio de Janeiro: Civilização Brasileira, 1972.

LARANJEIRA, J. P. A poesia 'é-sou' negra. Acta Scientiarum. LanguageandCulture, v. 32, n. 1, p. 35-41, 2010.

MOLINA, D. A. Luiz Gama. A vida como prova inconcussa da história. Estud. av., São Paulo, v. 32, n. 92, p. 147-165, 2018.

NABUCO, J. O abolicionismo. Rio de Janeiro: Civilização Brasileira, 1938.

OLIVEIRA, M. L. F. Luís Gama: poeta, republicano, abolicionista - 180 anos de nascimento. Folder de divulgação da exposição Luís Gama: poeta, republicano, abolicionista. Museu da cidade de São Paulo, 2010.

OLIVEIRA VIANNA, F. J. Raça e assimilação. Rio de Janeiro: José Olympio Editora, 1959 [1932].

RAMOS, J. S. Ciência e racismo: uma leitura crítica de raça e assimilação em Oliveira Vianna. História, Ciências, Saúde-Manguinhos. Rio de Janeiro, v.10, n. 2, p. 573-601, 2003.

RAMOS, J. S. Dos males que vêm com o sangue: as representações raciais e a categoria do imigrante indesejável nas concepções sobre imigração da década de 20. In: MAIO, M. C.; Ventura, R. (Orgs.). Raça, Ciência e Sociedade. Rio de Janeiro: Editora FIOCRUZ, 1996, p. 59-84.

SANTOS, S. A. Educação: um pensamento negro contemporâneo. Jundiaí: Paco Editorial, 2014.

SANTOS, S. A. A Formação do mercado de trabalho livre em São Paulo: tensões raciais e marginalização social. Dissertação (Mestrado em Sociologia)-Universidade de Brasília, Brasília, 1997.

SCHWARCZ, L. M. O espetáculo das raças. Cientistas, instituições e questão racial no Brasil. 1870 - 1930. São Paulo: Companhia das Letras, 1993. 
SENKEVICS, A. A cor e a raça nos censos demográficos nacionais. Geledés Instituto da Mulher Negra. Publicado em 23 de fevereiro de 2015. Disponível em: https://ensaiosdegenero.wordpress.com/2015/02/13/a-cor-e-a-raca-noscensos-demograficos-nacionais/. Acesso em: 09 dez. 2018.

TOURAINE, A. Crítica da modernidade. Petrópolis: Vozes, 1994.

VEIGA, E. Luís Gama (1830-1882): enfim, advogado. Estadão. Publicado em 30 de outubro de 2015. Disponível em: http://sao-

paulo.estadao.com.br/blogs/edison-veiga/luiz-gama-1830-1882-enfimadvogado/. Acesso em: 07 dez. 2018.

Recebido em: 12 de março de 2020 Aprovado em: 06 de junho de 2020 Publicado em: 31 de agosto de 2020 